\title{
DEFINIÇÃO DE PROPRIEDADES E CARACTERÍSTICAS DE COMPONENTES BIM COMUNS A PARTIR DO ENERGYPLUS 1
}

\author{
DEFINITION OF PROPERTIES AND CHARACTERISTICS OF COMMON BIM \\ COMPONENTS FROM ENERGYPLUS
}

\author{
Sérgio Leal Ferreira \\ Departamento de Engenharia de Construção Civil, USP \\ sergio.leal@usp.br
}

\begin{abstract}
Resumo
A Associação Brasileira de Normas Técnicas tem empreendido um esforço desde 2009 para normalizar elementos necessários para um bom desenvolvimento do BIM (Building Information Modeling) no Brasil. Dentre esses esforços, um grupo de trabalho foi criado mais recentemente com a finalidade de orientar a indústria para criar componentes BIM que contenham propriedades e dados necessários a uma modelagem eficiente. Dessa forma, esses componentes estarão preparados para o uso em análises específicas. Uma das análises previstas é a de Eficiência Energética das Edificações. O Diretório de Ferramentas de Simulações Computacionais do Departamento de Energia dos EUA fornece atualmente informações sobre 417 programas para a avaliação energética computacional de edificações e o EnergyPlus se apresenta como a melhor alternativa. Este trabalho apresenta o resultado do estudo dos dados do EnergyPlus no que se refere aos componentes mais comuns na arquitetura, como portas e janelas, e demonstra o caminho que é necessário percorrer dentro do Dicionário de Dados da Interface para encontrar todos os dados vinculados aos objetos utilizados no arquivo de entrada de dados. Como resultado, se apresenta o método de extração das informações e se discute a ampliação da sua aplicação para os diversos tipos de componentes presentes em um modelo BIM.
\end{abstract}

Palavras-chave: Componentes BIM. Eficiência Energética. EnergyPlus. Modelagem da Informação da Construção.

\begin{abstract}
The Brazilian Association of Technical Standards is making an effort since 2009 to standardize necessary elements to a well-done development of BIM (Building Information Modeling) in Brazil. Among these efforts, it was recently created a workgroup with the purpose of give support to the industry in the creation of BIM components that contain properties and data necessary to an efficient modeling. Consequently, these components will be ready to be used in specific analyses. One of the predicted analyses is Building Energy Efficiency. Building Energy Software Tools Directory provides information about 417 building software tools for evaluating energy efficiency, and EnergyPlus is the best alternative presented. This work shows the results of the EnergyPlus data analysis in the field of the most common components in architecture, like doors and windows, and demonstrates the pathway inside the Interface Data Dictionary to find all linked data to the objects used in the input data file. As a result, it will be presented the information extracting method and the discussions about the application of the method to extract information about all other components included in the BIM model.
\end{abstract}

Keywords: BIM components, Building Energy Efficiency, EnergyPlus, Building Information Modeling.

DOI: http://dx.doi.org/10.1606/gtp.v10i2.102600

\footnotetext{
${ }^{1}$ Ferreira, Sérgio Leal. Definição de Propriedades e Características de componentes BIM comuns a partir do EnergyPlus. In: ENCONTRO BRASILEIRO DE TECNOLOGIA DE INFORMAÇÃO E COMUNICAÇÃO NA CONSTRUÇÃO, 7. 2015. Recife. Anais... Porto Alegre: ANTAC, 2015.
} 